\title{
ERRATUM
}

\section{Carbohydrate anomalies in the PDB}

Jon Agirre, Gideon Davies, Keith Wilson \& Kevin Cowtan

Nat. Chem. Biol. 11, 303 (2015); published online 17 April 2015; corrected after print 17 June 2015

In the version of this article initially printed, the shorthand label in Figure 1 for the preferred chair conformation (top structure shown) was incorrectly shown as ${ }^{1} \mathrm{C}_{4}$ instead of ${ }^{4} \mathrm{C}_{1}$. The figure is correct in the HTML and PDF versions of the article.

\section{ERRATUM}

\section{Table of contents}

Nat. Chem. Biol. 11 (2015); published online 18 March 2015; corrected after print 17 June 2015

In the version of this table of contents initially printed, the description of the Books \& Arts article was incorrect. It should read "Translational research: Drug discovery from the inside." This information is correct in the HTML and PDF versions of the table of contents. 